\title{
Apigenin in the regulation of cholesterol metabolism and protection of blood vessels
}

\author{
KUN ZHANG ${ }^{1,2}$, WEI SONG ${ }^{3}$, DALIN LI ${ }^{1}$ and XING JIN ${ }^{2}$ \\ ${ }^{1}$ Department of Vascular Surgery, Qingdao Municipal Hospital, Qingdao, Shandong 266011; ${ }^{2}$ Department of \\ Vascular Surgery, Shandong Provincial Hospital Affiliated to Shandong University, Jinan, Shandong 250021; \\ ${ }^{3}$ Department of Endocrinology, Qingdao Municipal Hospital, Qingdao, Shandong 266011, P.R. China
}

Received July 1, 2016; Accepted December 13, 2016

DOI: $10.3892 / \mathrm{etm} .2017 .4165$

\begin{abstract}
Hyperlipidemia is a major independent risk factor for atherosclerosis. Seeking natural compounds in medicinal plants capable of reducing blood fat and studying their mechanisms of action has been the focus of research in recent years. The aim of the present study was to analyze the mechanisms of apigenin in regulating cholesterol metabolism and protecting blood vessels, and to provide a theoretical basis for the clinical application of apigenin. The mouse model of hyperlipidemia was established to verify the efficacy of apigenin in improving hyperlipidemia and to observe the mechanism of action of apigenin in reducing cholesterol content. In vitro cell experiments were conducted to evaluate the role of apigenin in mediating reverse cholesterol transport. Additionally, $\mathrm{H}_{2} \mathrm{O}_{2}$-injured human umbilical venous endothelial cells (EA.hy926 cells) were used for further study on the roles of apigenin in resisting oxidization and protecting vascular endothelial cells. Apigenin significantly regulated blood fat, reduced animal weight, and reduced total cholesterol $(\mathrm{P}=0.024)$, triglyceride $(\mathrm{P}=0.031)$ and low-density lipoprotein cholesterol $(\mathrm{P}=0.014)$ in the serum of the high-fat diet mice. Apigenin improved the blood lipid metabolism of the hyperlipidemia model mice. Body weight and serum cholesterol content increased abnormally $(\mathrm{P}=0.003)$ as a consequence of high-fat diet. Apigenin increased the activity of superoxide dismutase in EA.hy926 cells $(\mathrm{P}=0.043)$ and increased the amount of nitric oxide secreted by the cells $(\mathrm{P}=0.038)$. Apigenin also inhibited the proliferation of vascular smooth muscle cells in a dose-dependent manner $(\mathrm{P}=0.036)$. In conclusion, apigenin can regulate cholesterol metabolism in vivo and plays a role in reducing the level of blood fat by
\end{abstract}

Correspondence to: Dr Wei Song, Department of Endocrinology, Qingdao Municipal Hospital, 1 Jiaozhou Road, Qingdao, Shandong 266011, P.R. China

E-mail: songweishandong@163.com

Key words: apigenin, hyperlipidemia, atherosclerosis, reverse cholesterol transport, vascular endothelial cells promoting cholesterol absorption and conversion, and accelerating reverse cholesterol transport. Apigenin also has a role in resisting oxidization and protecting blood vessels.

\section{Introduction}

Atherosclerosis is one of the most important causes of cardiovascular and cerebrovascular diseases. Among the causes of atherosclerosis, hyperlipidemia is a major independent risk factor (1). The search for natural compounds capable of reducing blood fat and the study of their mechanism of action has been the focus of research in recent years as such compounds have significant prospective applications and social benefits. Apigenin is a flavonoid compound distributed extensively in vegetables and fruits grown in the temperate and tropical zones. Its content is particularly high in celery (2). Its content is also high in some medicinal plants such as Semen Plantaginis and Chinese Star Jasmine Stem. It is also distributed in some plant-derived beverages such as tea and alcohol, and in condiments $(3,4)$.

Research in recent years has indicated that apigenin has many active physiological functions: i) It exerts significant anticancer effects during the three major stages of cancer: Initiation, promotion, and progression. Furthermore, it has positive therapeutic effects against breast cancer, colon cancer, and melanoma (5-7); ii) it exerts spasmolytic, antihypertensive, and vasodilator effects $(8,9)$; iii) it exerts anti-inflammatory effects by inhibiting the high expression of nitric oxide (NO) synthase by macrophages (10); iv) it exerts sedative and anxiolytic effects by enhancing $\gamma$-aminobutyric acid neurotransmission $(11,12)$; and v) it exerts inhibitory effects against multiple gram-negative bacteria $(13,14)$.

In terms of cholesterol regulation, previous studies have shown that the flavonoid constituent has no significant effect on blood lipid metabolism, while apigenin plays a significant role in regulating blood fat. It can reduce the body weight of animals and decrease the levels of total cholesterol (TC), triglyceride (TG) and low-density lipoprotein cholesterol (LDL-C) in the serum of the high-fat model mouse. Therefore, three key proteins, HMG-CoAR, LDL-R, and CYP7A1, involved in cholesterol synthesis, absorption, and metabolism have been studied $(15,16)$ by measuring their expression at the level of mRNA using RT-PCR to determine 
the effect of apigenin on cholesterol metabolism. In terms of blood pressure reduction and vasodilation, research has indicated that apigenin can dilate the contracted aortic ring of rats caused by phenylephrine in vitro. Experiments have shown that apigenin can inhibit the proliferation of vascular smooth muscle cells in a dose-dependent manner within a certain concentration range (17), suggesting that apigenin is important in preventing cardiovascular diseases such as hypertension and atherosclerosis.

Animal models of hyperlipidemia have been established by means of a high-fat diet and have been used to study intervention with apigenin to observe its effect and mechanism of action in regulating blood fat and to understand the effective constituents capable of regulating cholesterol metabolism with apigenin. In terms of protective effect on endothelial cells, the present study aimed to observe the antagonistic effect of apigenin on hydrogen peroxide $\left(\mathrm{H}_{2} \mathrm{O}_{2}\right)$-induced injury and to understand the effect of apigenin on improving the functions of vascular endothelial cells (EA.hy926 cells). The results indicated that the antioxidant effect of apigenin and its role in protecting vascular endothelial cells occurred by increasing the activity of intracellular superoxide dismutase (SOD) and the secretion of NO. In addition, apigenin can inhibit the proliferation of vascular smooth muscle cells in a dose-dependent manner and may have the potential to inhibit thickening of vascular walls (17).

The present study involved the establishment of a mouse model of hyperlipidemia, and verification of the efficacy of apigenin in improving hyperlipidemia, and analysis of the mechanism of action of apigenin in reducing cholesterol content. Additionally, the roles of apigenin in reverse cholesterol transport, inhibition of the formation of foam cells, and resisting oxidization and protecting vascular endothelial cells were studied. The study provides further evidence for the role of apigenin in regulating cholesterol metabolism, suggesting it may be used for clinical treatment of cardiovascular and cerebrovascular diseases.

\section{Materials and methods}

Animal source and feed. Sixty female ICR mice (class II) weighing 18-20 g were purchased from the Laboratory Animal Center of Shandong University. The mice were raised in a clean animal room [no. SYXK (Inner Mongolia) 20050036]. Experiments began after 1 week of adaptive feeding. The animals were given access to food and water ad libitum during experiments. All the feed and potable water were disinfected.

Grouping and modeling. The mice were divided into six groups: Normal control group, high-fat animal model group, apigenin (Research Institution of Medicinal Plants of Chinese Academy of Medical Sciences, Beijing, China) low-dosage group, apigenin moderate-dosage group, apigenin high-dosage group, and simvastatin (R\&D Systems, Wiesbaden, Germany) group, with 12 mice each. The daily dosage of the positive control drug, simvastatin, was $12 \mathrm{mg} / \mathrm{kg}$. Sodium methyl cellulose (Sigma-Aldrich, St. Louis, MO, USA) was used as the solvent for preparation of drug suspensions. The mice were administered apigenin or simvastatin by intragastric injection once per day for 28 consecutive days. Mice in the control group and model group were administered intragastric injections of equal volumes of solvent. The method for establishing the hyperlipidemia mouse model was by feeding mice a high-fat diet (Biosino Bio-Technology and Science, Inc., Beijing, China). The animals in the normal group were fed with basal feed and the modeling continued for 28 days.

Cell culture. THP-1 cells were cultured with RPMI-1640 medium containing $10 \%$ fetal bovine serum (FBS) (Gibco BRL, Life Technologies Inc., Grand Island, NY, USA) containing $100 \mathrm{U} / \mathrm{ml}$ penicillin and $100 \mathrm{U} / \mathrm{ml}$ streptomycin at $37^{\circ} \mathrm{C}$ in an environment containing $5 \% \mathrm{CO}_{2}$. Media were changed every 2-3 days. Human umbilical venous endothelial cells (EA.hy926) and vascular smooth muscle cells (A10) were cultured in low-sugar Dulbecco's modified Eagle's medium (DMEM) containing 10\% FBS, $100 \mathrm{U} / \mathrm{ml}$ penicillin and $100 \mathrm{U} / \mathrm{ml}$ streptomycin in a constant-temperature incubator containing $5 \% \mathrm{CO}_{2}$ at $37^{\circ} \mathrm{C}$.

Establishment of macrophage-derived foam cell model. Macrophage-derived foam cells were prepared as previously described (18). THP-1 cells were cultured in RPMI-1640 containing $10 \%$ FBS. The cells were centrifuged at $8,000 \mathrm{x} \mathrm{g}$ for $5 \mathrm{~min}$, re-suspended, counted, and seeded in 6-well microplates at a density of $1.5 \times 10^{5}$ cells/well. The cells were divided into five groups: Normal group, model group, apigenin high-dosage group, apigenin moderate-dosage group, apigenin low-dosage group, and simvastatin group. Each condition was tested in triplicate. The cells were differentiated into macrophages by PMA induction (Sigma-Aldrich) for $48 \mathrm{~h}$. The liquid in each well was discarded. The cells were washed three times with PBS. Serum-free RPMI-1640 culture medium was then added to each well. The appropriate solutions were added to each group for pre-treatment. The cells were then incubated for $24 \mathrm{~h}$. The solution was changed every $24 \mathrm{~h}$. The cells were cultured for an additional $48 \mathrm{~h}$.

Determination of TC, $H D L-C$, and glucose content in serum. Total serum cholesterol was measured with a biochemical analyzer (Hitachi, Ltd., Tokyo, Japan).

Determination of blood fat and hepatic lipid content. The content of TC, TG, HDL-C, and LDL-C in serum of the mice in the various groups were determined in accordance with the instructions of the blood fat assay kit (Biosino Bio-Technology and Science, Inc.). The formula for calculating the atherosclerosis (AS) index was: AS index $=$ [(TC-HDL-C)/HDL-C]. Determination of the hepatic lipid content: $0.4 \mathrm{~g}$ of liver tissue was weighed, placed in a mechanical homogenizer, cut into pieces with scissors, and ground after addition of $4 \mathrm{ml}$ Folch solution. Homogenates were placed at $4^{\circ} \mathrm{C}$ for $24 \mathrm{~h}$ and occasionally subjected to vibration. Then, $2 \mathrm{ml}$ of the extracting solution was used to wash the test tube after it was filtered through a funnel. Samples were poured onto filter paper and $2 \mathrm{ml}$ of normal saline was added. The samples were mixed well and allowed to stand for 1.5-2 h. The samples were then centrifuged for $10 \mathrm{~min}$ at $1,500 \mathrm{x} \mathrm{g}$ following stratification. The solutions at the upper and middle levels were pipetted and discarded. Samples were then steamed in a water bath at $75^{\circ} \mathrm{C}$ 
until the presence of a thick, yellow jelly-like lipid appeared. Dried test tubes were cooled down at room temperature. Solutions were then mixed following the addition of $0.4 \mathrm{ml}$ of ethanol and centrifuged for $10 \mathrm{~min}$ at $1,500 \mathrm{x} \mathrm{g}$. A volume of $0.2 \mathrm{ml}$ of supernatant ethanol solution was then taken. It was agitated and mixed well. Determination was performed following $6 \mathrm{~min}$ in a water-bath.

Detection of cholesterol in the cellular supernatant and intracellular $\left[{ }^{3} \mathrm{H}\right]$. A volume of $1 \mathrm{ml}$ of cell culture medium was aspirated from each well. Then, $7 \mathrm{ml}$ of methylbenzeneTriton scintillation solution (Millipore, Billerica, MA, USA) was added. Plates were mixed and placed in an LS 6500 liquid scintillation analyzer (Thermo Fisher Scientific, Waltham, MA, USA). The CPM was calculated in the supernatant of the various groups of cells. Then, $1 \mathrm{ml}$ of $0.1 \mathrm{~mol} / 1 \mathrm{NaOH}$ was added to each well. The cells were agitated occasionally to cause cell lysis until all adherent cells were floating as observed under a microscope (Thermo Fisher Scientific). The formula to calculate cholesterol outflow rate (\%) was: The cholesterol outflow rate $(\%)=$ supernatant CPM (supernatant $\mathrm{CPM}+$ cell lysis buffer CPM) $\mathrm{x} 100 \%$.

Detection of NO content in the cell culture medium. Samples were mixed well, allowed to stand for $10 \mathrm{~min}$ and centrifuged at 2,500 $\mathrm{x}$ g for $10 \mathrm{~min}$. The clarified supernatant (ml) and color developing agent (ml) (Sigma-Aldrich, Munich, Germany) were mixed. The optical density (OD) value was measured at $15 \mathrm{~min}$ (Thermo Fisher Scientific). The $550 \mathrm{~nm}$ colorimetric $\mathrm{NO}(\mathrm{mol} / \mathrm{l})=(\mathrm{OD}$ value of the test tube - OD value of the blank tube)/(OD value of the standard tube - OD value of the blank tube) $\mathrm{x}$ standard tube concentration $(20 \mu \mathrm{mol} / \mathrm{l}) \mathrm{x}$ dilution ratio before sample testing.

Determination of activity of intracellular SOD. Cell disruption solution $(100 \mu \mathrm{l})$ was taken from each well. The activity of intracellular SOD was determined according to the instructions of the SOD kit (Nanjing Jiancheng Bioengineering Institute, Nanjing, China). The formula was: SOD activity $(\mathrm{U} / \mathrm{mg}$ protein $)$ in tissue $=$ absorbance of the control tube - absorbance of the test tube, absorbance of the control tube $/ 50 \% \mathrm{x}$ dilution ratio of the reaction system/protein content in the tissue $(\mathrm{mg} / \mathrm{ml})$.

Expression of $m R N A$ related to hepatic cholesterol. All of the following reagents were from Qiagen, Inc. (Valencia, CA, USA). A mass of $0.5 \mathrm{~g}$ of liver tissue was treated with $1 \mathrm{ml}$ TRIzol. The samples were vortexed and allowed to stand for $5 \mathrm{~min}$ at room temperature. After addition of roughly $1 / 5$ volume of chloroform, samples were inverted, mixed for $1 \mathrm{~min}$, allowed to stand for $5 \mathrm{~min}$ at room temperature, and centrifuged $\left(15 \mathrm{~min}, 6,000 \mathrm{x} \mathrm{g}, 4^{\circ} \mathrm{C}\right)$. After addition of an equivalent volume of isopropanol, samples were inverted and mixed, allowed to stand for $10 \mathrm{~min}$ at room temperature, and centrifuged $\left(10 \mathrm{~min}, 6,000 \mathrm{x} \mathrm{g}, 4^{\circ} \mathrm{C}\right)$. The supernatant was discarded. A volume of $1 \mathrm{ml}$ of $75 \%$ ethanol was added. An appropriate volume of DEPC water was added for intensive dissolution and precipitation. The total volume of the reaction system was $25 \mu \mathrm{l}$ including: $20 \mu \mathrm{l}$ fluorescent RT-PCR reaction solution, $1 \mu \mathrm{l}$ DNA polymerase, $0.35 \mu 1$ reverse transcriptase,
Table I. Primer sequences.

\begin{tabular}{ll} 
Gene name & \multicolumn{2}{c}{ Sequences } \\
\hline GAPDH & U: 5'-ATTCATGTGATCGACCATCC-3' \\
& D: 5'-CTCATCGCTGATCGGGTGAA-3' \\
HMG-CoAR & U: 5'-CAATGTGCGTCACAGAATGT-3' \\
& D: 5'-CTTGGCGTACTCCTTGAACA-3' \\
LDL-R & U: 5'-TGATCGATGTCGATGCGTGTACG-3' \\
& D: 5'-ATATGTGTCGATGCTCAGTCTTCC-3' \\
CYP7A1 & U: 5'-GGATGCTACGTACGTGTGCTAGC-3' \\
& D: 5'-GGGTCTAGTCGTACGCTTGCGTC-3'
\end{tabular}

U, upstream; D, downstream.

and $5 \mu$ l template RNA. The reaction mixtures were mixed well, and centrifuged at 3,000 x g for $10 \mathrm{sec}$. The thermal profile was as follows: Reverse transcription for $30 \mathrm{~min}$ at $50^{\circ} \mathrm{C}$; pre-denaturation for $3 \mathrm{~min}$ at $95^{\circ} \mathrm{C}$; denaturation for $15 \mathrm{sec}$ at $95^{\circ} \mathrm{C}$; annealing for $30 \mathrm{sec}$ at $50^{\circ} \mathrm{C}$, extension for $30 \mathrm{~min}$ at $72^{\circ} \mathrm{C}$, for five cycles in total; denaturation for $10 \mathrm{sec}$ at $95^{\circ} \mathrm{C}$; and annealing for $40 \mathrm{sec}$ at $55^{\circ} \mathrm{C}$, for 40 cycles in total. Primer sequences are shown in Table I.

Statistical analysis. Data were analyzed with SPSS 16.0 statistical software (SPSS, Inc., Chicago, IL, USA). One-way ANOVA test was used for comparisons between groups. $\mathrm{P}<0.05$ was taken as statistically significant. $\mathrm{P}<0.01$ was taken as highly statistically significant.

\section{Results}

Effect of apigenin on parameters of the high-fat model. There were no statistically significant differences in body weight among the various groups before the experiments $(\mathrm{P}>0.05)$. Body weight, hepatic coefficient, and AS index in the model group were significantly higher than in the control group $(\mathrm{P}<0.05)$. Body weight, hepatic coefficient, and AS index in the apigenin treatment group decreased with increasing dose, indicating that apigenin significantly reduced body weight and prevented development of atherosclerosis. The total serum cholesterol of mice in the model group was significantly higher than that in the normal control group $(\mathrm{P}<0.01)$. Apigenin and simvastatin decreased the levels of blood fat in mice. Serum TC of the mice in the apigenin group decreased with increasing dose $(\mathrm{P}<0.01)$. The concentrations of $\mathrm{TG}$ and LDL-C in serum of mice in the model group increased significantly compared with the normal control group $(\mathrm{P}<0.01)$. The concentrations of TG and LDL-C in sera of mice in the model group were 1.34- and 2.56-fold those in the normal group. The content of TC and TG in the liver of mice in the model group increased significantly and the activity of SOD in serum decreased significantly $(\mathrm{P}<0.01)$ compared with the normal control group. This indicated that the high-fat diet raised the levels of hepatic lipid in mice, abnormally increased lipid content, and inhibited the activity of SOD in vivo. SOD activity in serum of mice in the apigenin group increased by $20.95 \%$ compared with the model group $(\mathrm{P}<0.01)$ (Table II). 
Table II. Effect of apigenin on body weight, liver weight, AS index, TC, LDL-C, and SOD (mean \pm SD) of the high-fat model mice.

\begin{tabular}{lccccccccc}
\hline Groups & $\begin{array}{c}\text { Initial body } \\
\text { weight }\end{array}$ & $\begin{array}{c}\text { Final body } \\
\text { weight }\end{array}$ & $\begin{array}{c}\text { Liver } \\
\text { weight }\end{array}$ & AS index & Initial TC & Final TC & TG & LDL-C & SOD \\
\hline $\begin{array}{l}\text { Control } \\
\text { Model }\end{array}$ & $22.05 \pm 1.40$ & $34.05 \pm 1.58$ & $3.49 \pm 0.45$ & $0.58 \pm 0.29$ & $2.13 \pm 0.25$ & $2.68 \pm 0.53$ & $1.90 \pm 0.34$ & $0.57 \pm 0.26$ & $150.18 \pm 9.98$ \\
$\begin{array}{l}\text { Low-dose } \\
\text { apigenin }\end{array}$ & $22.68 \pm 2.01$ & $36.94 \pm 2.07^{\mathrm{a}}$ & $4.08 \pm 0.40^{\mathrm{a}}$ & $1.04 \pm 0.58^{\mathrm{b}}$ & $2.30 \pm 0.46$ & $4.53 \pm 1.19^{\mathrm{a}}$ & $2.56 \pm 0.78^{\mathrm{a}}$ & $1.78 \pm 0.78^{\mathrm{a}}$ & $113.56 \pm 21.09^{\mathrm{a}}$ \\
$\begin{array}{l}\text { Moderate-dose } \\
\text { apigenin }\end{array}$ & $23.78 \pm 1.81$ & $36.91 \pm 1.74$ & $3.9 \pm 0.4$ & $1.05 \pm 0.67$ & $2.35 \pm 0.24$ & $4.34 \pm 0.81$ & $2.56 \pm 0.87$ & $1.50 \pm 0.73^{\mathrm{c}}$ & $125.34 \pm 18.65$ \\
$\begin{array}{l}\text { High-dose } \\
\text { apigenin }\end{array}$ & $22.58 \pm 2.00$ & $34.97 \pm 2.03^{\mathrm{d}}$ & $3.79 \pm 0.36$ & $0.67 \pm 0.33^{\mathrm{d}}$ & $2.39 \pm 0.34$ & $3.29 \pm 0.89^{\mathrm{c}}$ & $2.14 \pm 0.54^{\mathrm{d}}$ & $0.80 \pm 9.54^{\mathrm{d}}$ & $127.38 \pm 20.90^{\mathrm{c}}$ \\
$\begin{array}{l}\text { Simvastatin } \\
\text { Simven }\end{array}$ & $23.06 \pm 1.61$ & $35.88 \pm 2.21$ & $3.87 \pm 0.39$ & $0.66 \pm 0.22^{\mathrm{d}}$ & $2.30 \pm 0.42$ & $4.01 \pm 1.12^{\mathrm{c}}$ & $2.16 \pm 0.54^{\mathrm{d}}$ & $1.08 \pm 0.50^{\mathrm{c}}$ & $136.76 \pm 19.98^{\mathrm{d}}$ \\
\hline
\end{tabular}

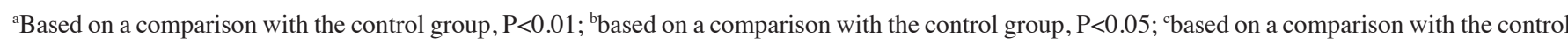
group, $\mathrm{P}<0.01$; ${ }^{\text {bbased }}$ on a comparison with the control group, $\mathrm{P}<0.05$. AS, atherosclerosis; TC, total cholesterol; LDL-C, low-density lipoprotein cholesterol; SOD, superoxide dismutase; TG, triglyceride.

$\mathbf{A}$

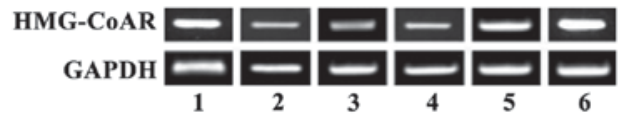

B
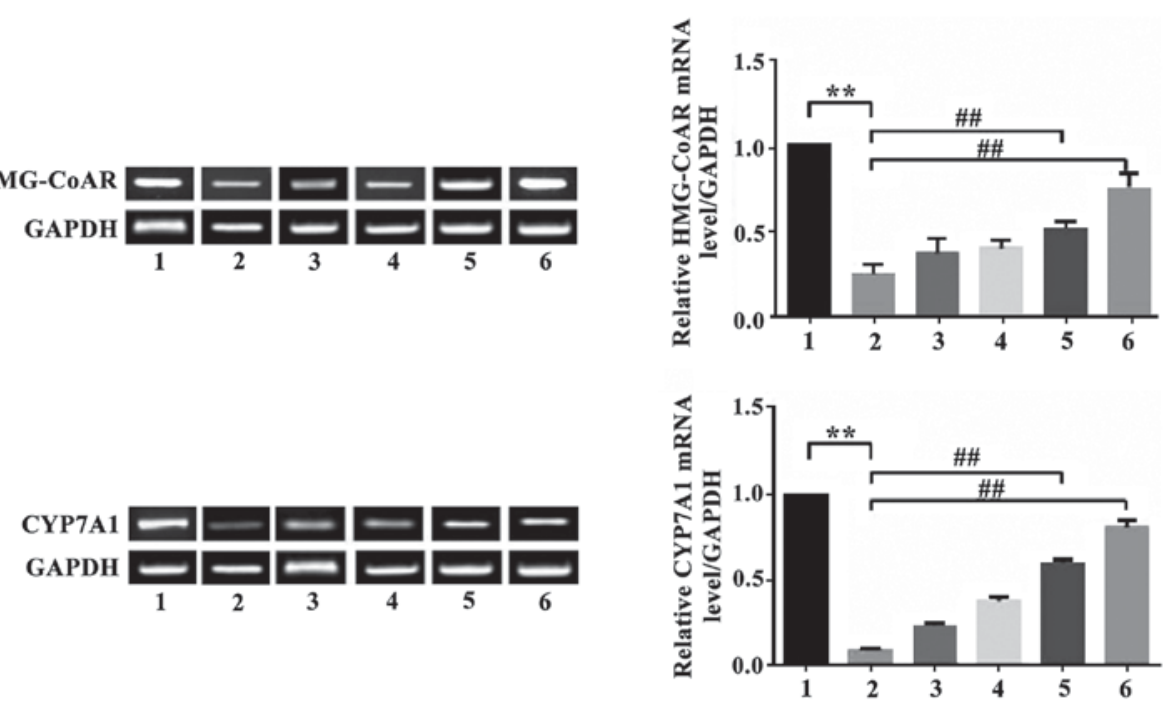

C

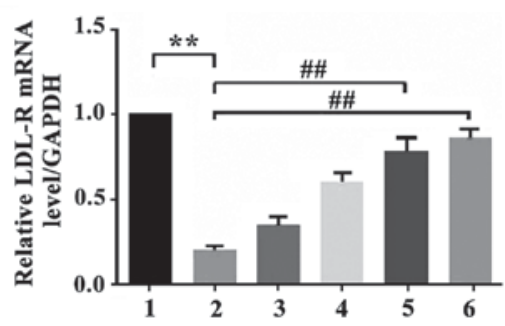

Figure 1. Expression of LDL-R. Based on a comparison with the control group, $\mathrm{P}<0.01$; ${ }^{* *}$ Based on a comparison with the model group, ${ }^{\# \#} \mathrm{P}<0.01$. Lane 1, control group; lane 2, model group; lane 3, low-dose apigenin group; lane 4, moderate-dose apigenin group; lane 5, high-dose apigenin group; lane 6 , simvastatin group.

Effect of apigenin on expression of HMG-CoAR, CYP7Al and LDL-R mRNA in the liver of mice with hyperlipidemia. The expression of HMG-CoAR mRNA in hepatic tissue of mice in the model group decreased significantly $(\mathrm{P}<0.01)$ compared with the normal control group. Apigenin was able to upregulate the inhibited expression of HMG-CoAR mRNA. The expression of HMG-CoAR mRNA in the liver of animals in the apigenin high-dosage group and the simvastatin group increased significantly compared with the model group $(\mathrm{P}<0.01)$. The expression of CYP7A1 mRNA in hepatic tissue of mice in the model group was significantly lower than in the normal control group $(\mathrm{P}<0.01)$. Apigenin was able to reverse the decreased expression level of CYP7A1 mRNA. The expression of CYP7A1 mRNA in the liver of the apigenin high-dosage group was significantly higher than in the model group $(\mathrm{P}<0.01)$. The expression of LDL-R mRNA 
Table III. Effect of apigenin on the efflux of $\left[{ }^{3} \mathrm{H}\right]$ cholesterol in macrophages and the ratio of cholesteryl ester/TC.

\begin{tabular}{|c|c|c|c|c|c|}
\hline Groups & Dose $(\mathrm{mol} / \mathrm{l})$ & $\begin{array}{c}\text { Cholesterol } \\
\text { efflux rate }(\%)\end{array}$ & $\mathrm{TC}(\mathrm{mg} / \mathrm{g})$ & $\begin{array}{l}\text { Cholesteryl } \\
\text { ester (mg/g) }\end{array}$ & $\begin{array}{c}\text { Cholesteryl } \\
\text { ester/TC }(\%)\end{array}$ \\
\hline Control & - & $8.76 \pm 1.34$ & $11.58 \pm 1.03$ & $4.08 \pm 0.76$ & $32.56 \pm 2.34$ \\
\hline Model & - & $7.58 \pm 1.43$ & $30.58 \pm 1.58$ & $15.46 \pm 0.65$ & $60.45 \pm 5.54$ \\
\hline High-dose apigenin & $3 \times 10^{-5}$ & $14.58 \pm 1.76^{\mathrm{b}}$ & $18.96 \pm 1.67^{\mathrm{b}}$ & $8.04 \pm 1.45$ & $43.67 \pm 5.67$ \\
\hline Moderate-dose apigenin & $3 \times 10^{-6}$ & $11.23 \pm 1.34^{\mathrm{a}}$ & $22.34 \pm 1.56^{\mathrm{a}}$ & $10.76 \pm 0.54^{\mathrm{a}}$ & $50.87 \pm 3.45^{\mathrm{a}}$ \\
\hline Low-dose apigenin & $3 \times 10^{-7}$ & $10.67 \pm 1.23$ & $29.67 \pm 1.08$ & $13.45 \pm 0.87^{\mathrm{b}}$ & $51.23 \pm 5.67^{\mathrm{b}}$ \\
\hline
\end{tabular}

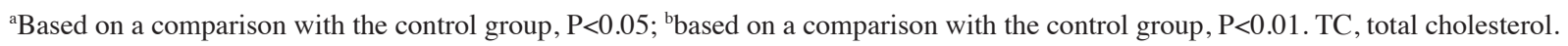

Table IV. Effect of apigenin on the activity of NO and SOD secreted by $\mathrm{H}_{2} \mathrm{O}_{2}$-injured EA.hy926 cells.

\begin{tabular}{lcccc}
\hline Groups & Dose & Activity $(\%)$ & NO $(\mu \mathrm{mol} / \mathrm{l})$ & SOD $(\mathrm{U} / \mathrm{mg})$ \\
\hline Control & - & - & $40.67 \pm 2.87$ & $56.34 \pm 7.45$ \\
$\mathrm{H}_{2} \mathrm{O}_{2}$ & $75 \mu \mathrm{mol} / 1$ & - & $24.56 \pm 1.76^{\mathrm{a}}$ & $33.25 \pm 5.28^{\mathrm{a}}$ \\
High-dose apigenin & $1 \times 10^{-5} \mathrm{~mol} / \mathrm{l}$ & $80.45^{\mathrm{c}}$ & $36.57 \pm 2.48^{\mathrm{c}}$ & $44.67 \pm 4.56^{\mathrm{b}}$ \\
Moderate-dose apigenin & $1 \times 10^{-6} \mathrm{~mol} / 1$ & $40.19^{\mathrm{c}}$ & $22.56 \pm 2.16$ & $40.15 \pm 3.40$ \\
Low-dose apigenin & $1 \times 10^{-7} \mathrm{~mol} / 1$ & 9.89 & $19.45 \pm 1.45$ & $33.67 \pm 1.34$ \\
\hline
\end{tabular}

${ }^{a} \mathrm{P}<0.01$ vs. control group; ${ }^{b} \mathrm{P}<0.05$, ${ }^{\mathrm{c}} \mathrm{P}<0.01$ vs. $\mathrm{H}_{2} \mathrm{O}_{2}$ group. NO, nitric oxide; $\mathrm{SOD}$, superoxide dismutase; $\mathrm{H}_{2} \mathrm{O}_{2}$, hydrogen peroxide.

in the liver of mice of the apigenin high-dosage group and the low-dosage group increased significantly compared with the model group $(\mathrm{P}<0.01$ and $\mathrm{P}<0.05)$. There were no statistical differences in expression of LDL-R mRNA in the liver between mice in the apigenin treatment group and the model group ( $\mathrm{P}>0.05)$ (Fig. 1).

Effect of apigenin on efflux of cholesterol $\left[{ }^{3} \mathrm{H}\right]$ and cholesteryl ester/TC ratio. As shown in Table III, 24-h incubation of THP-1 cells with apigenin significantly promoted the efflux rate of $\left[{ }^{3} \mathrm{H}\right]$ cholesterol from THP-1 cells $(\mathrm{P}<0.01)$ in a dose-dependent manner. The efflux rate of $\left[{ }^{3} \mathrm{H}\right]$ cholesterol in the cells of the apigenin high-dosage group increased by $51.68 \%$ compared with the normal group. The efflux rate of $\left[{ }^{3} \mathrm{H}\right]$ cholesterol in cells of the apigenin moderate-dosage group increased by $31.88 \%$. This indicated that apigenin promoted the efflux of cholesterol in macrophages and reduced the content of intracellular cholesterol. This also indicated that apigenin was able to regulate cholesterol metabolism in macrophages, increase the flow of cholesterol from the inside to the outside of macrophages, and reduce the accumulation of intracellular cholesterol. The content of cholesteryl ester and the ratio of cholesteryl ester to TC increased by 4.05 -fold and 1.58 -fold compared with the normal group.

Effect of apigenin on $\mathrm{NO}$ and SOD secretion by EA.hy926 cells injured by $\mathrm{H}_{2} \mathrm{O}_{2} \cdot \mathrm{H}_{2} \mathrm{O}_{2}$ oxidative damage significantly decreased the levels of NO generated by EA.hy926 cells. The levels of NO secreted by the injured cells only reached $60.52 \%$ of the NO concentration of the normal control group $(\mathrm{P}<0.01)$. Apigenin reversed the effect of $\mathrm{H}_{2} \mathrm{O}_{2}$-injury in a dose-dependent manner and raised the level of NO secreted by
$\mathrm{H}_{2} \mathrm{O}_{2}$-injured EA.hy926 cells. A concentration of $1 \times 10^{-5} \mathrm{~mol} / \mathrm{l}$ apigenin caused the levels of NO secreted by injured EA.hy926 cells to rise by $40.86 \%(\mathrm{P}<0.01)$. Based on comparison with the control group, incubation of EA.hy926 cells with $\mathrm{H}_{2} \mathrm{O}_{2}$ lead to a significant decrease of $37.62 \%$ of intracellular SOD activity. Apigenin weakly inhibited the proliferation of A10 vascular smooth muscle cells, and there was a dose-dependent trend. However, there were no significant differences in the inhibitory effects among the three doses of apigenin $(\mathrm{P}>0.05)$. High-dose apigenin significantly inhibited the proliferation of A10 cells $(\mathrm{P}<0.01)$ (Table IV) and the inhibitory effect was dose-dependent.

\section{Discussion}

In the present study, the high-fat diet mouse model of hyperlipidemia was reproduced. The levels of TC, TG, and LDL-C in serum of the model mice increased significantly at 4 weeks exposure to a high-fat diet, indicating successful establishment of the model of hyperlipidemia. The results indicated that apigenin reduced the content of TC, TG, and LDL-C in mice in a dose-dependent manner. Administration of apigenin significantly decreased body weight; concentrations of TC, TG, and LDL-C in serum; and the content of TC and TG, suggesting that apigenin effectively inhibited rising levels of blood lipid, improved disorder of cholesterol metabolism, mitigated accumulation of hepatic lipid, and recovered the balance of lipid metabolism. The data suggest that apigenin can help prevent and treat atherosclerosis and decrease the incidence of cardiovascular and cerebrovascular diseases.

To understand the mechanism of action of apigenin in reducing blood fat, the mRNA levels corresponding 
to three key proteins involved in cholesterol metabolism (HMG-CoAR, CYP7A1, and LDL-R) were examined by RT-PCR. HMG-CoAR is a rate-limiting enzyme for cholesterol synthesis in the liver. CYP7A1 is a key enzyme which transforms cholesterol into bile acid in liver (19). LDL-R is an important receptor that mediates liver uptake of LDL-C (20). It was shown in the present study that the mRNA levels of HMG-CoAR, CYP7A1, and LDL-R in the liver of mice of the model group decreased significantly following exposure to a high-fat diet compared with those in the normal control group. The results are consistent with other studies in the literature. The results indicate that administration of apigenin can cause the expression levels of these genes to approximate normal levels (21).

During the development of atherosclerosis, oxidative stress induces the expression of vascular adhesion molecules, promotes local inflammatory reactions, and induces cell proliferation (22). Hyperlipidemia can increase the amount of oxygen free radicals generated in vivo (23), increase oxidative stress (24) and is involved in the occurrence and progression of atherosclerosis. It was shown in the present study that SOD activity of mice in the model group decreased and the antagonistic effect against oxidative stress was inhibited. Apigenin can increase SOD activity, increase anti-oxidative capacity in vivo, reduce the amount of oxidative low-density lipoprotein produced, and inhibits development of atherosclerosis.

The above results indicated that apigenin significantly decreased the levels of TC, TG, and LDL-C in serum of mice with hyperlipidemia and reduced the accumulation of TC and TG in the liver. Apigenin may decrease the content of cholesterol by promoting hepatic LDL-C absorption and increasing the transformation of hepatic cholesterol into bile acid. The present study also showed that apigenin can improve the dysregulated lipid balance and can potentially be used to treat diseases such as atherosclerosis and fatty liver. The results of the present study provide a foundation for further research on the mechanism of action of apigenin in regulating cholesterol metabolism.

\section{References}

1. Liu-Smith F and Meyskens FL: Molecular mechanisms of flavonoids in melanin synthesis and the potential for the prevention and treatment of melanoma. Mol Nutr Food Res 60: 1264-1274, 2016.

2. Yarla NS, Bishayee A, Sethi G, Reddanna P, Kalle AM, Dhananjaya BL, Dowluru KS, Chintala R and Duddukuri GR: Targeting arachidonic acid pathway by natural products for cancer prevention and therapy. Semin Cancer Biol: Feb 4, 2016 (Epub ahead of print). doi: 10.1016/j.semcancer.2016.02.001.

3. Moosavi F, Hosseini R, Saso L and Firuzi O: Modulation of neurotrophic signaling pathways by polyphenols. Drug Des Devel Ther 10: 23-42, 2015.

4. Venigalla M, Sonego S, Gyengesi E, Sharman MJ and Münch G: Novel promising therapeutics against chronic neuroinflammation and neurodegeneration in Alzheimer's disease. Neurochem Int 95: 63-74, 2016.

5. Venigalla M, Gyengesi E and Münch G: Curcumin and apigenin - novel and promising therapeutics against chronic neuroinflammation in Alzheimer's disease. Neural Regen Res 10 1181-1185, 2015.

6. Shakeri F and Boskabady MH: A review of the relaxant effect of various medicinal plants on tracheal smooth muscle, their possible mechanism(s) and potency. J Ethnopharmacol 175: $528-548,2015$
7. Sak K: Cytotoxicity of dietary flavonoids on different human cancer types. Pharmacogn Rev 8: 122-146, 2014.

8. Maurya SK, Kushwaha AK and Seth A: Ethnomedicinal review of Usnakantaka (Echinops echinatus Roxb.). Pharmacogn Rev 9: 149-154, 2015.

9. Armstrong CM and Gao AC: Drug resistance in castration resistant prostate cancer: resistance mechanisms and emerging treatment strategies. Am J Clin Exp Urol 3: 64-76, 2015.

10. Shay J, Elbaz HA, Lee I, Zielske SP, Malek MH and Hüttemann M: Molecular mechanisms and therapeutic effects of (-)-epicatechin and other polyphenols in cancer, inflammation, diabetes, and neurodegeneration. Oxid Med Cell Longev 2015: 181260, 2015

11. Johnston GA: Flavonoid nutraceuticals and ionotropic receptors for the inhibitory neurotransmitter GABA. Neurochem Int 89: 120-125, 2015.

12. Guedj F, Bianchi DW and Delabar JM: Prenatal treatment of Down syndrome: a reality? Curr Opin Obstet Gynecol 26: 92-103, 2014

13. Fernando W, Rupasinghe HP and Hoskin DW: Regulation of hypoxia-inducible factor- $1 \alpha$ and vascular endothelial growth factor signaling by plant flavonoids. Mini Rev Med Chem 15: 479-489, 2015.

14. Li A, Sun A, Liu R, Zhang Y and Cui J: An efficient preparative procedure for main flavonoids from the peel of Trichosanthes kirilowii Maxim. using polyamide resin followed by semi-preparative high performance liquid chromatography. J Chromatogr B Analyt Technol Biomed Life Sci 965: 150-157, 2014.

15. Nabavi SM, Habtemariam S, Daglia M and Nabavi SF: Apigenin and Breast Cancers: from Chemistry to Medicine. Anticancer Agents Med Chem 15: 728-735, 2015.

16. Gupta SC, Tyagi AK, Deshmukh-Taskar P, Hinojosa M, Prasad S and Aggarwal BB: Downregulation of tumor necrosis factor and other proinflammatory biomarkers by polyphenols. Arch Biochem Biophys 559: 91-99, 2014.

17. Cochran DB, Gray LN, Anderson KW and Dziubla TD: Degradable poly(apigenin) polymer inhibits tumor cell adhesion to vascular endothelial cells. J Biomed Mater Res B Appl Biomater: Aug 6, 2015 (Epub ahead of print). doi: 10.1002/jbm.b.33486.

18. Mastantuono T, Battiloro L, Sabatino L, Chiurazzi M, Di Maro M, Muscariello E, Colantuoni A and Lapi D: Effects of citrus flavonoids against microvascular damage induced by hypoperfusion and reperfusion in rat pial circulation. Microcirculation 22: 378-390, 2015.

19. Alig SK, Stampnik Y, Pircher J, Rotter R, Gaitzsch E, Ribeiro A, Wörnle M, Krötz F and Mannell H: The tyrosine phosphatase SHP-1 regulates hypoxia inducible factor- $1 \alpha$ (HIF-1 $\alpha)$ protein levels in endothelial cells under hypoxia. PLoS One 10: e0121113, 2015.

20. Zargaran A, Borhani-Haghighi A, Faridi P, Daneshamouz S, Kordafshari $\mathrm{G}$ and Mohagheghzadeh A: Potential effect and mechanism of action of topical chamomile (Matricaria chammomila L.) oil on migraine headache: a medical hypothesis. Med Hypotheses 83: 566-569, 2014.

21. Chen X, Jin J, Chen Y, Peng L, Zhong G, Li J, Bi H, Cai Y and Huang M: Effect of scutellarin on the metabolism and pharmacokinetics of clopidogrel in rats. Biopharm Drug Dispos 36: 64-68, 2015.

22. Seo HS, Ku JM, Choi HS, Woo JK, Jang BH, Go H, Shin YC and Ko SG: Apigenin induces caspase-dependent apoptosis by inhibiting signal transducer and activator of transcription 3 signaling in HER2-overexpressing SKBR3 breast cancer cells. Mol Med Rep 12: 2977-2984, 2015.

23. Chen YJ, Wang L, Zhou GY, Yu XL, Zhang YH, Hu N, Li QQ, Chen C, Qing C, Liu YT, et al: Scutellarin attenuates endothelium-dependent vasodilation impairment induced by hypoxia reoxygenation, through regulating the $\mathrm{PKG}$ signaling pathway in rat coronary artery. Chin J Nat Med 13: 264-273, 2015.

24. Lee W, Yoon EK, Kim KM, Park DH and Bae JS: Antiseptic effect of vicenin-2 and scolymoside from Cyclopia subternata (honeybush) in response to HMGB1 as a late sepsis mediator in vitro and in vivo. Can J Physiol Pharmacol 93: 709-720, 2015. 